\title{
TATA KELOLA SEKOLAH EFEKTIF MENUJU SEKOLAH YANG BERKUALITAS
}

\author{
Endang Retnoningsih \\ Email : endangretningsih72@gmail.com
}

\begin{abstract}
The effective school assessment model is one of the instruments that is expected to be used by education managers to determine the level of success of each school. The results of the assessment can then be taken into consideration for efforts to improve schools. Schools that have a good, transparent and accountable management system, and are able to empower every important component of the school, both internally and externally, in order to achieve the vision and mission goals of the school effectively and efficiently. The concept of an effective school is a school that is able to optimize all the inputs and processes for the achievement of educational output, namely school achievement, especially student achievement marked by having all the abilities in the form of competencies required in learning. The characteristics of an effective school are: 1) the leadership of the principal is strong. 2) high expectations of student achievement, 3) emphasizing basic skills, and 4) orderliness and controlled atmosphere. Effective school leadership by the principal because the principal is a figure (key person) in realizing the vision, mission, and goals of the school, which is an effective and efficient school
\end{abstract}

Keywords: School Management, Effective and Excellent

\begin{abstract}
ABSTRAK
Model penilaian sekolah efektif merupakan salah satu instrumen yang diharapkan dapat digunakan oleh pengelola pendidikan untuk mengetahui tingkat keberhasilan setiap sekolah. Hasil penilaian tersebut selanjutnya dapat dijadikan bahan pertimbangan untuk melakukan upaya perbaikan sekolah. Sekolah yang memiliki sistem pengelolaan yang baik, transparan dan akuntabel, serta mampu memberdayakan setiap komponen penting sekolah, baik secara internal maupun eksternal, dalam rangka pencapaian visi-misi-tujuan sekolah secara efektif dan efesien. Konsep sekolah efektif adalah sekolah yang mampu mengoptimalkan semua masukan dan proses bagi ketercapaian output pendidikan, yaitu prestasi sekolah terutama prestasi siswa yang ditandai dengan dimilikinya semua kemampuan berupa kompetensi yang dipersyaratkan didalam belajar. Karekteristik sekolah efektif yaitu: 1) kepemimpinan kepala sekolah kuat. 2) harapan yang tinggi terhadap prestasi pelajar, 3) menekankan pada keterampilan dasar, dan 4) keteraturan dan atmosfer terkendali. Kepemimpinan sekolah efektif oleh kepala Sekolah karena Kepala sekolah merupakan figure (key person) dalam mewujudkan visi, misi dan tujuan sekolah yaitu sekolah yang efektif dan efesien
\end{abstract}

Kata Kunci: Manajemen Sekolah, Efektif dan Unggul 


\section{PENDAHULUAN}

Keberhasilan sebuah lembaga pendidikan sangat ditentukan oleh peran kepemimpinan kepala sekolah. Karena kepala sekolah sebagai pemimpin di lembaganya, maka kepala sekolah harus mampu membawa lembaga ke arah tercapainya tujuan yang telah di tentukan. Kepala sekolah harus mampu melihat adanya perubahan terhadap regulasi pendidikan dan kehidupan globalisasi.

Keunggulan suatu bangsa tidak lagi bertumpu pada kekayaan alam, melainkan pada keunggulan sumber daya manusia (SDM), yaitu tenaga terdidik yang mampu menjawab tantangan-tantangan yang sangat cepat. Secara keseluruhan, di Indonesia mutu SDM Indonesia saat ini masih ketinggalan dan berada di belakang SDM negara-negara maju dan negaranegara tetangga, seperti Malaysia dan Thailand. Kenyataan ini sudah lebih dari cukup untuk mendorong pakar dan praktisi pendidikan melakukan kajian sistematik untuk membenahi atau memperbaiki sistem pendidikan nasional.

Agar keluaran dari sekolah mampu beradaptasi secara dinamis dengan perubahan dan tantangan tersebut, pemerintah melontarkan gagasan tentang manajemen pendidikan yang berbasis sekolah (school-based management) yang memberikan ruang yang luas bagi sekolah dan masyarakatnya untuk menentukan program dan rencana pengembangan diri sesuai dengan kebutuhan dan kondisi masing-masing (Sulfemi dan Nunung, 2019).

Sejalan dengan gagasan desentralisasi pengelolaan pendidikan, maka fungsi-fungsi pengelolaan sekolah perlu diberdayakan secara maksimal agar dapat berjalan secara efektif untuk menghasilkan mutu lulusan yang diharapkan oleh masyarakat dan bangsa. Hal tersebut perlu didukung oleh seperangkat instrument yang akan mendorong sekolah berupaya meningkatkan efektivitas fungsi-fungsi pengelolaannya secara terus-menerus sehingga mampu berkembang menjadi learning organization. (Sulfemi dan Nurhasanah, 2018).

Melalui makalah ini kami mencoba menjelaskan untuk bisa mempelajari dan memahami tentang sekolah efektif yang merupakan sebuah terobosan dalam dunia pendidikan.

\section{METOLOGI}

Penelitian ini menggunakan pendekatan kualitatif, yaitu dengan menekankan analisisnya pada proses penyimpulan komparasi serta pada analisis terhadap dinamika hubungan fenomena yang diamati dengan menggunakan logika ilmiah. Penelitian kualitatif merupakan pendekatan yang menghasilkan data 
deskriptif berupa kata-kata tertulis dari orang-orang yang diamati yang tidak dituangkan ke dalam istilah yang digunakan dalam penelitian kuantitatif. Dalam penelitian ini digunakan riset kepustakaan. Penelitihan pustaka atau riset pustaka ialah serangkaian kegiatan yang berkenaan dengan metode pengumpulan data pustaka, membaca dan mencatat serta mengolah bahan koleksi perpustakaan saja tanpa memerlukan riset lapangan.

Penelitian ini akan menampilkan argumentasi penalaran keilmuan dari hasil kajian pustaka dan hasil olah pikir peneliti mengenai suatu masalah atau topik kajian. Jenis penelitian ini didukung oleh data yang diperoleh dari sumber pustaka yang berupa jurnal penelitian, skripsi, laporan penelitian, buku teks, makalah, laporan seminar, diskusi ilmiah, dan lain sebagainya. Bahan-bahan pustaka tersebut dibahas secara kritis dan mendalam dalam rangka mendukung pembahasan. Teknik Pengumpulan Data dalam penulis hasil karya tulis ini berupa buku dan jurnal, kemudian membaca dan mencatat bahanbahan yang diperlukan untuk memperoleh informasi yang bekaitan dengan pembahasan

\section{PEMBAHASAN}

Sekolah merupakan suatu institusi yang didalamnya terdapat komponen guru, siswa, dan staf administrasi yang masing- masing mempunyai tugas tertentu dalam melancarkan program. Sebagai institusi pendidikan formal, sekolah dituntut menghasilkan lulusan yang mempunyai kemampuan akademis tertentu, keterampilan, sikap dan mental, serta kepribadian lainnya sehingga mereka dapat melanjutkan ke jenjang pendidikan yang lebih tinggi atau bekerja pada lapangan pekerjaan yang membutuhkan keahlian dan keterampilannya. Keberhasilan sekolah merupakan ukuran bersifat mikro yang didasarkan pada tujuan dan sasaran pendidikan pada tingkat sekolah sejalan dengan tujuan pendidikan nasional serta sejauh mana tujuan itu dapat dicapai pada periode tertentu sesuai dengan lamanya pendidikan yang berlangsung di sekolah. (Sulfemi, 2019).

Berdasarkan sudut pandang keberhasilan sekolah tersebut, kemudian dikenal sekolah efektif dan efisien yang mengacu pada sejauh mana sekolah dapat mencapai tujuan dan sasaran pendidikan yag telah ditetapkan. Dengan kata lain, sekolah disebut efektif jika sekolah tersebut dapat mencapai apa yang telah direncanakan. Pengertian umum sekolah efektif juga berkaitan dengan perumusan apa yang harus dikerjakan dengan apa yang telah dicapai. Sehingga suatu sekolah akan disebut efektif jika terdapat hubungan yang kuat antara apa yang telah dirumuskan untuk dikerjakan dengan 
hasil-hasil yang dicapai oleh sekolah, sebaliknya sekolah dikatakan tidak efektif bila hubungan tersebut rendah (Getzel, 1969).

Sekolah efektif adalah sekolah yang dapat mencapai target yang telah ditetapkannya sendiri. Sekolah unggul dan efektif adalah sekolah yang dapat mencapai target dengan penetapan target yang tinggi. Peter Mortimore (1996) menyampaikan sekolah efektif dapat diartikan sebagai "A high performing school, through its well-established system promotes the highest academic and other achievements for the maximum number of students regardless of its socio-economic background of the families". Selanjutnya Taylor (1990) mendefinisikan sekolah efektif sebagai sekolah yang mengorgansiasikan dan memanfaatkan semua sumber daya yang dimilikinya untuk menjamin semua siswa (tanpa memandang ras, jenis kelamin maupun status sosial ekonomi) bisa mempelajari materi kurikulum yang esensial di sekolah. (Sulfemi dan Desmiati, 2018).

Menurut

Cheng (1996) mendefinisikan sekolah efektif sebagai sekolah yang memiliki kemampuan dalam menjalankan fungsinya secara maksimal, baik fungsi ekonomis, fungsi sosial kemanusiaan, fungsi politis, fungsi budaya maupun fungsi pendidikan. Fungsi ekonomis sekolah adalah memberi bekal kepada siswa agar dapat melakukan aktivitas ekonomi sehingga dapat hidup sejahtera. Fungsi social kemanusiaan adalah sekolah sebagai media bagi siswa untuk beradaptasi dengan kehidupan masyarakat. Fungsi politis sekolah adalah sebagai wahana untuk memperoleh pengetahuan tentang hak dan kewajiban sebagai warganegara. Fungsi budaya sekolah adalah media untuk melakukan transmisi dan transformasi budaya. Adapun fungsi pendidikan adalah sekolah sebagai wahana untuk proses pendewasaan dan pembentukan kepribadian siswa (Sulfemi dan Mayasari, 2019).

Efektifitas sekolah menunjukkan adanya proses perekayasaan berbagai sumber dan metode yang diarahkan pada terjadinya pembelajaran di sekolah secara optimal. Efektifitas sekolah merujuk pada pemberdayaan semua komponen sekolah sebagai organisasi tempat belajar berdasarkan tugas pokok dan fungsinya masing-masing dalam struktur program dengan tujuan agar siswa belajar dan mencapai hasil yang telah ditetapkan yaitu memiliki kompetensi. Pada sekolah efektif seluruh siswa tidak hanya yang memiliki kemampuan tinggi dalam belajar tetapi juga yang memiliki kemampuan intelektualitas yang biasapun dapat mengembangkan dirinya sejauh mungkin jika dibandingkan dengan kondisi awal 
ketika rnereka baru memasuki sekolah (Sulfemi, 2019).

Simpulan dari sekolah efektif yang dapat ditarik dari penjelasan-penjelasan di atas adalah sekolah yang mampu mengoptimalkan semua masukan dan proses bagi ketercapaian output pendidikan yaitu prestasi sekolah terutama prestasi siswa yang ditandai dengan dimilikinya semua kemampuan berupa kompetensi yang dipersyaratkan di dalam belajar. (Sulfemi, 2017).

Konsep Sekolah Efektif muncul berdasarkan hasil Meta riset yang dilakukan di berbagai Negara. Riset awal membuktikan. Di Amerika Serikat, Coleman (1966) melaporkan "Siswa yang berprestasi tinggi di sekolah, melanjutkan ke jenjang yang lebih tinggi, dan hidupnya berhasil adalah siswa yang berasal dari keluarga yang sosial ekonominya tinggi. Sedangkan siswa yang prestasinya rendah, tidak mampu belajar di sekolah, drop out, tidak melanjutkan ke jenjang yang lebih tinggi, tidak mempunyai motivasi belajar adalah siswa yang berasal dari keluarga yang sosial ekonominya rendah. Di Inggris, ROBBINS (1962) melaporkan bahwa Hampir semua siswa yang melanjutkan ke jenjang perguruan tinggi berasal dari keluarga yang ayahnya mempunyai profesi yang tinggi. Hanya $2 \%$ siswa yang melanjutkan ke jenjang perguruan tinggi berasal dari keluarga yang ayahnya tidak mempunyai kecakapan atau pendidikan yang memadai. Pusat Penelitian Pengukuran dan Evaluasi NSW, (1960-1970) Australia, menyimpulkan bahwa pendapat atau pandangan orang tua tentang nilai-nilai pendidikan sangat berpengaruh terhadap prestasi pembelajaran anak di sekolah. Berdasarkan pendapat atau pandangan orang tua tersebut, dapat diprediksi prestasi siswa di sekolah, kapan siswa drop out, dan jenis pekerjaan apa yang akan ditekuninya.

Pada kenyataannya, ada sekolahsekolah yang secara konsisten menghasilkan siswa-siswa berprestasi tinggi, melanjutkan ke jenjang yang lebih tinggi dan lebih berhasil hidupnya, apapun latar belakang keluarga siswa. Di Inggris, hasil penelitian Rutter (tahun 1979) melaporkan bahwa sekolah tersebut memiliki ciri-ciri : menekankan pada pembelajaran, guru merencanakan bersama dan bekerja sama dalam pelaksanaan pembelajaran, dan ada supervisi yang terarah dari guru senior dan kepala sekolah. (Sulfemi, 2018).

Di Amerika Serikat, penelitian Weber (1971), Austin (1978), Brookeover \& Lezotte (1979), Edmonds \& Frederickson (1979), Phi Delta Kappa (1980), secara meta analisis menyimpulkan bahwa sekolah tersebut mempunyai ciri: kepemimpinannya kuat, 
memiliki harapan yang tinggi bagi siswa dan guru, lingkungannya yang kondusif, kepala sekolah berperan sebagai "instructional leader", kemajuan prestasi belajar siswa sering dimonitor, dan adanya dukungan pelibatan orang tua secara aktif. Melalui pemeliharaan mutu, responsive terhadap tantangan dan antisipatif terhadap perubahan yang diakibatkan dari berubahnya tatanan internal sehingga tidak menimbulkan keadaan bergejolak akan mendukung kemajuan sekolah. Globalisasi menuntut dunia pendidikan bersinergi dengan berbagai perubahan melalui rekayasa menejemen pendidikan dengan tetap memegang citra diri bangsa. Sekolah yang hanya memelihara keadaan stabil tanpa merespon berbagai gejolak akan berhadapan dengan keadaan yang tidak menguntungkan. Sebagai peningkatan mutu pendidikan, lembaga pendidikan khususnya perguruan tinggi harus melakukan berbagai penataan. Salah satu upayannya adalah pembenahan dibidang menejemen. Manajemen yang baik akan menjadikan sekolah tersebut berhasil mencapai tujuan dan sasaran pendidikan. (Sulfemi, 2019).

Berdasarkan sudut pandang keberhasilan sekolah tersebut, kemudian dikenal dengan sekolah efektif. Pengertian umum sekolah efektif juga berkaitan dengan perumusan apa yang harus dikerjakan dengan apa yang harus dicapai.
Sehingga sekolah dikatakan efektif jika terdapat hubungan yang kuat antara apa yang telah dirumuskan untuk dikerjakan dengan hasil-hasil yang dicapai oleh sekolah. Efektifitas adalah ukuran yang menyatakan sejauh mana sasaran atau tujuan telah dicapai. Efektifitas sekolah terkait pula dengan kualitas. Kualitas adalah gambaran dan karakteristik menyeluruh yang menunjukan kemampuaannya dalam memuaskan kebutuhan yang ditentukan atau yang tersirat misalnya nilai hasil ujian akhir, prestasi olahraga, prestasi karya tulis ilmiah dan prestasi pentas seni. Kualitas lulusan dipengaruhi oleh tahapan-tahapan kegiatan sekolah yang saling berhubungan yaitu perencanaan, pelaksanaan dan evaluasi. Efektifitas sekolah menunjukan adanya proses perekayasaan berbagai sumber dan metode yang diarahkan pada terjadinya pembelajaran disekolah secara optimal. Efektifitas sekolah merujuk pada pemberdayaan semua komponen sekolah sebagai organisasi tempat belajar berdasarkan tugas pokok dan fungsinya masing-masing dalam struktur program dengan tujuan agar siswa belajar dan mencapai hasil yang telah ditetapkan, yaitu memiliki kompetensi. Pada sekolah efektif, semua siswa baik siswa yang mempunyai kemampuan tinggi dalam belajar, yang dapat mengembangkan diri, siswa yang memiliki kemampuan 
intelektualitas yang biasapun dapat mengembangkan dirinya, jika dibandingkan dengan kondisi awal ketika mereka baru memasuki sekolah. Dengan demikain konsep sekolah efektif adalah sekolah yang mampu mengoptimalkan semua masukan dan proses bagi ketercapaian output pendidikan, yaitu prestasi sekolah terutama prestasi siswa yang ditandai dengan dimilikinya semua kemampuan berupa kompetensi yang dipersyaratkan didalam belajar.

Esensi yang terkandung dalam bagian pendahuluan di atas adalah fungsi sekolah sebagai tempat belajar yang memiliki kewajiban untuk menyelenggarakan pengalaman pembelajaran yang bermutu bagi peserta didiknya. Esensi inilah yang menjadi misi atau tugas pokok sekolah, yang sepatutnya menjadi dasar bagi peserta didiknya dan analisis kinerja sekolah yang efektif.

Perspektif sekolah analisis kinerja sekolah yang efektif dapat dikemukakan berikut : Pertama, sekolah Efektif dalam Perspektif Mutu Pendidikan. Penyelenggaraan layanan belajar bagi peserta didik biasanya dikaji dalam konteks mutu pendidikan yang erat hubungannya dengan kajian kualitas manajemen dan sekolah efektif. Di lingkungan sistem persekolahan, konsep mutu pendidikan dipersepsi berbeda-beda oleh berbagai pihak. Menurut persepsi kebanyakan orang (orang tua dan masyarakat pada umumnya), mutu pendidikan di sekolah secara sederhana dilihat dan perolehan nilai atau angka yang dicapai seperti ditunjukkan dalam hasilhasil ulangan dan ujian. Sekolah dianggap bermutu apabila para siswanya, sebagian besar atau seluruhnya, memperoleh nilai atau angka yang tinggi, sehingga berpeluang melanjutkan ke jenjang pendidikan yang lebih tinggi.

Persepsi tersebut tidak keliru apabila nilai atau angka tersebut diakui sebagai representasi dari totalitas hasil belajar, yang dapat dipercaya menggambarkan derajat perubahan tingkah laku atau penguasaan kemampuan yang menyangkut aspek kognitif, afektif dan psikomotorik. Dengan demikian, hasil pendidikan yang bermutu memiliki nuansa kuantitatif dan kualitatif. Artinya, di samping ditunjukkan oleh indikator seberapa banyak siswa yang berprestasi sebagaimana dilihat dalam perolehan angka atau nilai yang tinggi, juga ditunjukkan oleh seberapa baik kepemilikan kualitas pribadi para siswanya, seperti tampak dalam kepercayaan diri, kemandirian, disiplin, kerja keras dan ulet, terampil, berbudipekerti, beriman dan bertaqwa, tanggung jawab sosial dan kebangsaan, apresiasi, dan lain sebagainya. Analisis di atas memberikan pemahaman yang jelas bahwa konsep sekolah efektif berkaitan langsung 
dengan mutu kinerja sekolah (Sulfemi, 2019).

Kemampuan umum yang dimiliki seorang anak biasanya dipergunakan sebagai prediktor untuk menjelaskan tingkat kemampuan menyelesaikan program belajar, sehingga kemampuan ini sering disebut sebagai scholastic aptitude atau potensi akademik. Seorang siswa yang memiliki potensi akademik yang tinggi diduga memiliki kemampuan yang tinggi pula untuk menyelesaikan programprogram belajar atau tugas-tugas belajar pada umumnya di sekolah, dan karenanya diperhitungkan akan memperoleh prestasi yang diharapkan.

Sementara itu, kemampuan khusus atau bakat dijadikan prediktor untuk berprestasi dengan baik dalam bidang kajian khusus seperti dalam bidang karya seni, musik, akting dan sejenisnya. Atas dasar pemahaman ini, maka untuk memperoleh mutu pendidikan sekolah yang baik, para siswa yang dilayaninya harus memiliki potensi yang memadai untuk menyelesaikan program-program belajar yang dituntut oleh kurikulum sekolah. Kemampuan profesional guru direfleksikan pada mutu pengalaman pembelajaran siswa yang berinteraksi dalam kondisi proses belajar mengajar. Kondisi ini sangat dipengaruhi oleh: 1) tingkat penguasaan guru terhadap bahan pelajaran dan penguasaan struktur konsep- konsep keilmuannya. 2) metode, pendekatan, gaya atau seni dan prosedur mengajar, pemanfaatan, fasilitas belajar secara efektif dan efisien. 3) pemahaman guru terhadap karateristik kelompok dan perorangan siswa. 4) kemampuan guru menciptakan dialog kreatif dan menciptakan lingkungan belajar yang menyenangkan. 5) kepribadian guru.

Atas dasar analisis tersebut, maka upaya untuk meningkatkan mutu pendidikan di sekolah harus disertai dengan upaya-upaya untuk meningkatkan kemampuan profesional dan memperbaiki kualitas kepribadian gurunya. Pada tingkat sekolah, upaya tersebut ditunjukkan dalam kegiatan-kegiatan berikut, yaitu: 1) interaksi kolegialitas di antara guru-guru. 2) pemahaman proses-proses kognitif dalam penyelenggaraan pengajaran.3) penguasaan struktur pengetahuan mata pelajaran. 4) pemilikan pemahaman dan penghayatan terhadap nilai, keyakinan, dan standar. 5) keterampilan mengajar, 6) pengetahuan bagaimana siswa belajar.

Fasilitas belajar menyangkut ketersediaan hal-hal yang dapat memberikan kemudahan bagi perolehan pengalaman belajar yang efektif dan efisien. Fasilitas belajar yang sangat penting adalah perpustakaan, komputer, dan kondisi fisik lainnya yang secara langsung mempengaruhi kenyamanan belajar (Sulfemi, 2019). 
Budaya sekolah adalah seluruh pengalaman psikologis para siswa (sosial, emosional dan intelektual) yang diserap oleh mereka selama berada dalam lingkungan sekolah. Respon psikologis keseharian siswa terhadap hal-hal seperti cara-cara guru dan personil sekolah lainnya bersikap dan berperilaku (misalnya, layanan wali kelas dan tenaga administratif), implementasi kebijakan sekolah, kondisi dan layanan warung sekolah, penataan keindahan, kebersihan dan kenyamanan kampus, semuanya membentuk budaya sekolah. Budaya sekolah merembes pada penghayatan psikologis warga sekolah termasuk siswa, yang pada gilirannya membentuk pola nilai, sikap, kebiasaan dan perilaku. Aspek penting yang turut membentuk budaya sekolah adalah kepemimpinan sekolah. Kepemimpinan sekolah yang efektif merupakan sumber nilai dan semangat, sumber tatanan dan perilaku kelembagaan yang berorientasi ke arah dan sejalan dengan pencapaian visi dan misi sekolah. Oleh karena itu, kepala sekolah hendaklah seseorang yang memiliki visi dan misi kelembagaan, memiliki kemampuan konseptual, memiliki keterampilan dan seni dalam hubungan antarmanusia, menguasai aspek-aspek teknis dan substantif pekerjaannya, memiliki semangat untuk maju, serta memiliki semangat mengabdi dan karakter yang diterima oleh lingkungannya (Sulfemi, 2020).

Dari tema analisis sekolah efektif dalam perspektif mutu pendidikan dapat dikatakan bahwa sekolah yang efektif adalah sekolah yang: 1) memiliki masukan siswa dengan potensi yang sesuai dengan tuntutan kurikulum, 2) dapat menyediakan layanan pembelajaran yang bermutu, 3) memiliki fasilitas sekolah yang menunjang efektivitas dan efesiensi kegiatan belajar mengajar, dan 4) memiliki kemampuan menciptakan budaya sekolah yang kondusif sebagai refleksi dari kinerja kepemimpinan profesional kepala sekolah.

Kedua. Sekolah Efektif dalam Perspektif Manajemen. Manajemen sekolah merupakan proses pemanfaatan seluruh sumber daya sekolah yang dilakukan melalui tindakan yang rasional dan sistematik (mencakup perencanaan, pengorganisasian, pengerahan tindakan, dan pengendalian) untuk mencapai tujuan sekolah secara efektif dan efisien.

Tindakan-tindakan manajemen tersebut bersumber pada kebijakan dan peraturan-peraturan yang disepakati bersama yang diwujudkan dalam bentuk sikap, nilai, dan perilaku dari seluruh orang yang terlibat di dalamnya. Tindakan-tindakan manajemen tidak berlangsung dalam satu isolasi, melainkan terjadi dalam satu keutuhan kompleksitas sistem. Apabila dilihat dalam perspektif 
ini, maka dimensi sekolah efektif meliputi:

1). Layanan Belajar bagi Siswa, 3) Pengelolaan dan Layanan Siswa, 4) Sarana dan Prasarana Sekolah, 5) Program dan Pembiayaan. 6) Partisipasi Masyarakat, dan 7) Budaya Sekolah

Ketiga. Sekolah Efektif dalam Perspektif Teori Organisme. Sekolah efektif mampu mewujudkan apa yang disebut sebagai "self-renewing schools" atau "adaptive schools", atau disebut juga sebagai "learning organization" yaitu suatu kondisi di mana kelembagaan sekolah sebagai satu identitas mampu menangani permasalahan yang dihadapinya sementara menunjukkan kapabilitasnya dalam berinovasi. Menurut teori organisme, dunia ini bukan benda mati, melainkan merupakan suatu energi yang memiliki kapasitas berubah untuk menyesuaikan diri dengan lingkungannya. Dalam perspektif ini, maka bentuk kehidupan apa pun hanya akan mampu bertahan apabila organisme itu mampu memberikan respon yang tepat untuk beradaptasi dengan perubahanperubahan yang terjadi di sekitarnya.

David A. Squires, et.al. (1983) ciriciri sekolah efektif yaitu: 1) adanya standar disiplin yang berlaku bagi kepala sekolah, guru, siswa, dan karyawan di sekolah, 2) memiliki suatu keteraturan dalam rutinitas kegiatan di kelas; 3) mempunyai standar prestasi sekolah yang sangat tinggi; 4) siswa diharapkan mampu mencapai tujuan yang telah direncanakan; 5) siswa diharapkan lulus dengan menguasai pengetahuan akademik; 6) adanya penghargaan bagi siswa yang berprestasi; 7) siswa berpendapat kerja keras lebih penting dari pada faktor keberuntungan dalam meraih prestasi; 8) para siswa diharapkan mempunyai tanggung jawab yang diakui secara umum, kepala sekolah mempunyai program inservice, pengawasan, supervisi, serta menyediakan waktu untuk membuat rencana bersama-sama dengan para guru dan memungkinkan adanya umpan balik demi keberhasilan prestasi akademiknya.

Menurut Peter Mortimore (1991) sekolah efektif dicirikan sebagai berikut: (1) Sekolah memiliki visi dan misi yang jelas dan dijalankan dengan konsisten; (2) Lingkungan sekolah yang baik, dan adanya disiplin serta keteraturan di kalangan pelajar dan staf; Kepemimpinan kepala sekolah yang kuat; (4) Penghargaan bagi guru dan staf serta siswa yang berprestasi; (5) Pendelegasian wewenang yang jelas; (6) Dukungan masyarakat sekitar; (7) Sekolah mempunyai rancangan program yang jelas; (8) Sekolah mempunyai fokus sistemnya tersendiri; (9) Pelajar diberi tanggung jawab; (10) Guru menerapkan strategistrategi pembelajaran inovatif;

Evaluasi yang berkelanjutan;

Kurikulum sekolah yang terancang dan 
terintegrasi satu sama lain; (13) Melibatkan orang tua dan masyarakat dalam membantu pendidikan anakanaknya.

Shannon dan Bylsma (2005) mengidentifikasi 9 karakteristik sekolahsekolah berpenampilan unggul (high performing schools). Untuk mewujudkannya mereka berjuang dan bekerja keras dalam waktu yang relatif lama. Kesembilan karakteristik sekolah efektif berpenampilan unggul itu meliputi: 1) Fokus bersama dan jelas, 2) Standar dan harapan yang tinggi bagi semua siswa 3) Kepemimpinan sekolah yang efektif, 4) Tingkat kerja sama dan komunikasi inovatif, 5) Kurikulum, pembelajaran dan evaluasi yang melampaui standar, 6) Frekuensi pemantauan terhadap belajar dan mengajar tinggi, 7) Pengembangan staf pendidik dan tenaga kependidikan yang terfokus, 8) Lingkungan yang mendukung belajar, dan 9) Keterlibatan yang tinggi dari keluarga dan masyarakat

Apabila dikaitkan antara semua faktor sekolah efektif tersebut, tampak nyata bahwa semua faktor tersebut dalam tulisan ini juga dikenal sebagai dimensidimensi mutu pendidikan. Dengan kata lain, dapat disebutkan bahwa sekolah efektif tidak lain dan tidak bukan adalah juga sebutan untuk pendidikan yang bermutu. Pendidikan yang bermutu tidak hanya prestasi siswanya mencakup keunggulan akademik, tetapi juga nonakademik seperti keberhasilan dalam olahraga dan peningkatan gairah belajar.

Karena itu, ukuran keberhasilan prestasi siswa pun bukan hanya dilihat berdasarkan hasil-hasil ujian berupa angka melainkan juga aspek-aspek non kognitif seperti kehadiran, partisipasi aktif di kelas, dan bahkan angka drop out. Dan sekolah efektif juga memerlukan dukungan orangtua dan masyarakat, yang diwadahi dalam lembaga yang dikenal dengan Dewan Pendidikan dan Komite Sekolah.

Di Inggris, hasil penelitian Rutter (tahun 1979) melaporkan bahwa sekolah tersebut memiliki ciri-ciri: menekankan pada pembelajaran, guru merencanakan bersama dan bekerja sama dalam pelaksanaan pembelajaran, dan ada supervisi yang terarah dari guru senior dan kepsek di Amerika Serikat, penelitian Weber (1971), Austin (1978), Brookeover \& Lezotte (1979), Edmonds \& Frederickson (1979), Phi Delta Kappa (1980), secara meta analisis menyimpulkan bahwa sekolah tersebut mempunyai ciri: kepemimpinannya kuat, memiliki harapan yang tinggi bagi siswa dan guru, lingkungannya yang kondusif, kepala sekolah berperan sebagai 'instructional leader', kemajuan prestasi belajar siswa sering dimonitor, dan adanya dukungan pelibatan orang tua secara aktif. 
Jaap Scheerens (1992) sekolah yang efektif mempunyai lima ciri penting yaitu: 1) kepemimpinan yang kuat; 2) penekanan pada pencapaian kemampuan dasar; 3) adanya lingkungan yang nyaman; 4) harapan yang tinggi pada prestasi siswa; dan 5) penilaian secara rutin mengenai program yang dibuat siswa.

Mackenzie

mengidentifikasikan tiga dimensi pendidikan efektif yaitu kepemimpinan, keefektifan dan efisiensi serta unsur pokok dan penunjang masing-masing dimensi tersebut.

Pengetahuan lain mengenai sekolah efektif adalah sebagai berikut: 1) mampu mendemontrasikan kebolehannya mengenai seperangkat kriteria; 2) menetapkan sasaran yang jelas dan upaya untuk mencapainya; 3) adanya kepemimpinan yang kuat; 4) adanya hubungan yang baik antara sekolah dengan orangtua siswa;dan 4) pengembangan staf dan iklim sekolah yang kondusif untuk belajar

Ada empat komponen strategis dalam mencapai tujuan sekolah, yaitu: 1) komponen program. Program yang dimaksud yakni program yang terukur dan realistis sesuai dengan dinamika regulasi dan tuntutan zaman, 2) figure, yakni orang-orang dibalik program yang merupakan perancang sekaligus pelaku program, 3) culture, yakni etos kerja dan komitmen terhadap tugas pokok dan fungsinya, dan 4) budget, yakni berupa anggaran yang memadai dan memungkinkan tercapainya tujuan. Seperti yang dijelaskan Syafaruddin (2008: 180) bahwa sekolah efektif adalah sekolah yang skor prestasi pelajarnya tidak terlalu bervariasi dari segi status sosial-ekonomi.

Kemudian juga ada empat karakteristik sekolah efektif, yaitu: 1) kepemimpinan kepala sekolah kuat, 2) harapan yang tinggi terhadap prestasi pelajar. 3) menekankan pada keterampilan dasar. 4) keteraturan dan atmosfer terkendali.

Kepempinan kepala sekolah yang kuat akan sangat berpengaruh pada terwujudnya sekolah yang efektif. Hal tersebut dikarenakan Kepala Sekolah merupakan salah satu figure (key person) dalam mewujudkan visi, misi dan tujuan sekolah. Husaini Usman (2006: 469) berpendapat bahwa Kepala Sekolah sebagai manager di sekolah dituntut mengorganisir seluruh sumber daya sekolah menggunakan prinsip "Teamwork", yang mengandung pengertian adanya rasa kebersamaan (Together), pandai merasakan (Empathy), saling membantu (Assist), saling penuh kedewasaan (Maturity), saling mematuhi (Willingness), saling teratur (Organization), saling menghormati 
(Respect), dan saling berbaik hati (Kindness). (Sulfemi, 2018).

Selain dari itu Suyanto (2006 : 180) menjelaskan bahwa usaha meningkatkan efektivitas sekolah juga dapat dilakukan dengan mengaplikasikan empat teknik, yaitu: 1) School review, yakni suatu proses dimana seluruh komponen sekolah bekerja sama khususnya dengan orang tua dan tenaga profesional untuk mengevaluasi dan menilai efektivitas sekolah serta mutu lulusan; 2) Benchmarking, yakni kegiatan untuk menetapkan target yang akan dicapai dalam suatu periode tertentu; 3) Quality assurance, merupakan teknik untuk menentukan bahwa proses pendidikan telah berlangsung sebagaimana seharusnya. Informasi yang akan dihasilkan menjadi umpan balik bagi sekolah dan memberikan jaminan bagi orang tua bahwa sekolah senantiasa memberikan pelayanan terbaik; 4) Quality control merupakan suatu sistem untuk mendeteksi terjadinya penyimpangan kualitas output yang tidak sesuai dengan standar.

Selaku pemimpin di sekolah, Kepala Sekolah dituntut dapat menjalankan semua peran tersebut secara optimal. Dalam mewujudkan sekolah yang efektif, permasalahan terberat yang harus segera ditangani adalah penyediaan fasilitas yang mendukung potensi lokal dapat berkembang optimal.

\section{KESIMPULAN}

Dari pembahasan yang ada dapat disimpulkan bahwa: Sekolah sebagai suatu sistem, yaitu suatu kesatuan yang terdiri dari komponen-komponen yang saling berkaitan satu sama lain yang membentuk satu kesatuan yang utuh. Sedangkan sekolah itu sendiri terdiri dari beberapa komponen-komponen (input, proses dan output) yang saling berkaitan satu sama lain sehingga sekolah dapat dikatakan sebagai suatu sistem.

Pengertian sekolah efektif yaitu sekolah yang memiliki sistem pengelolaan yang baik, transparan dan akuntabel, serta mampu memberdayakan setiap komponen penting sekolah, baik secara internal maupun eksternal, dalam rangka pencapaian visi-misi-tujuan sekolah secara efektif dan efesien.

Konsep sekolah efektif adalah sekolah yang mampu mengoptimalkan semua masukan dan proses bagi ketercapaian output pendidikan, yaitu prestasi sekolah terutama prestasi siswa yang ditandai dengan dimilikinya semua kemampuan berupa kompetensi yang dipersyaratkan didalam belajar. Karekteristik sekolah efektif yaitu: 1) kepemimpinan kepala sekolah kuat. 2) harapan yang tinggi terhadap prestasi pelajar, 3) menekankan pada keterampilan dasar, dan 4) keteraturan dan atmosfer terkendali. Kepemimpinan sekolah efektif 
oleh kepala Sekolah karena Kepala sekolah merupakan figure (key person) dalam mewujudkan visi, misi dan tujuan sekolah yaitu sekolah yang efektif.

\section{DAFTAR PUSTAKA}

Arsyad, Arsyad dan Sulfemi, Wahyu Bagja. (2019). Korelasi Penguasaan Materi Pembelajaran Oleh Guru Dengan Motivasi Belajar Siswa Mata Pelajaran Administrasi Perkantoran di SMK Pelita Bogor.

Bidwel, Douglas M. Windham. (1980). The Analicis of Educational Productivity Volume II: Issues in Microanalicis. Ballinger Publishing Company: Massachusetts.

Buhler, Patricia. (2004). Management Skills. Jakarta : Prenada Media. Irawan, Prasetya. (1995). Analisis Kinerja (Panduan Praktis) Menganalisis Kinerja Organisasi, Kinerja Proses, dan Kinerja Pegawai. Jakarta: Universitas Indonesia.

Liang-Gie, T. (1994). Administrasi Perkantoran Modern. Yogyakarta: Liberty.

Manullang. (1990). Dasar-Dasar Manajemen. Jakarta: Ghalia Indonesia.

Philip B. Coss by (1979) Conformance to requipment, Armand V. Feigenbaum.

Palettei, Arsyad Djamaluddin, dan Sulfemi, Wahyu Bagja. (2019). Pengaruh Kelompok Kerja Guru (KKG) Terhadap Peningkatan Kompetensi Pedagogik dan Kemampuan Menulis Karya Ilmiah. Jurnal Pendidikan Dasar Indonesia Jurnal Pendidikan Dasar
Indonesia (JPDI). 7 (2). 53 58.DOI: http://dx.doi.org/10.2 6737/jpdi.v4i2.1522

Sedarmayanti (2001). Sumber Daya manusia dan Produktivitas Kerja. Bandung: Mandar Maju.

Sulfemi, Wahyu Bagja dan Supriyadi, Dede. (2018). Pengaruh Kemampuan Pedagogik Guru dengan Hasil Belajar IPS. Edutecno 17 (1), 1-10.

Sulfemi, Wahyu Bagja. (2018). Hubungan Motivasi Belajar Dengan Hasil Belajar IPS Di SMP Kabupaten Bogor. Edutecno $18(2), 1-8$.

Sulfemi, Wahyu Bagja. (2018). Pengaruh Disiplin Ibadah Sholat, Lingkungan Sekolah, dan Intelegensi Terhadap Hasil Belajar Peserta Didik Mata Pelajaran Pendidikan Agama Islam. Edukasi: Jurnal Penelitian Pendidikan Agama dan Keagamaan, 16 (2).

Sulfemi, Wahyu Bagja dan Nurhasanah. (2018). Penggunaan Metode Demontrasi dan Media Audio Visual Dalam Meningkatkan Hasil Belajar Peserta Didik Mata Pelajaran IPS. Jurnal Pendas Mahakam. 3 (2). 151158.

Sulfemi, Wahyu Bagja dan Setianingsih. (2018), Penggunaan Tames Games Tournament (TGT) Dengan Media Kartu Dalam Meningkatkan Hasil Belajar. Journal of Komodo Science Education (JKSE). 1 (1), 1-14.

Sulfemi, Wahyu Bagja dan Desmiati, Zulaicha. (2018). Model Pembelajaran Missouri Mathematics Project Berbantu Media Relief Experience dalam Meningkatkan Hasil Belajar Siswa. Jurnal Pendas Mahakam. 3 (3), 232-245. 
Sulfemi, Wahyu Bagja dan Hilga Minati. (2018). Meningkatkan Hasil Belajar Peserta Didik Kelas 3 SD Menggunakan Model Picture And Picture dan Media Gambar Seri. JPSD. 4 (2), 228- 242.

Sulfemi, Wahyu Bagja. (2018). Modul Manajemen Pendidikan Non Formal. Bogor: STKIP Muhammadiyah Bogor.

Sulfemi, Wahyu Bagja. (2019). Bergaul Tanpa Harus Menyakiti. Bogor : Visi Nusantara Maju.

Sulfemi, Wahyu Bagja. (2019). Model Pembelajaran Kooperatif Mind Mapping Berbantu Audio Visual Dalam Meningkatkan Minat, Motivasi dan Hasil Belajar IPS. Jurnal PIPSI (Jurnal Pendidikan IPS Indonesia), 4(1), 13-19. DOI: http://dx.doi.org/10.2673 7/jipips.v4i1.1204

Sulfemi, Wahyu Bagja dan Yuliani, Nunung. (2019). Model Pembelajaran Contextual Teaching And Learning (CTL) Berbantu Media Miniatur Lingkungan Untuk Meningkatkan Hasil Belajar IPS. Edunomic : Jurnal Ilmiah Pendidikan Ekonomi Fakultas Keguruan Dan Ilmu Pendidikan.7 (2). 73-84

Sulfemi, Wahyu Bagja dan Mayasari, Nova. (2019). Peranan Model Pembelajaran Value Clarification Technique Berbantuan Media Audio Visual Untuk Meningkatkan Hasil Belajar IPS. Jurnal Pendidikan. 20 (1). 53-68.

Sulfemi, Wahyu Bagja., \& Yuliana, D. (2019). Penerapan Model Pembelajaran Discovery Learning Meningkatkan Motivasi Dan Hasil Belajar Pendidikan

Kewarganegaraan. Jurnal
Rontal Keilmuan Pancasila dan Kewarganegaraan, 5(1), 17-30.

Sulfemi, Wahyu Bagja dan Mayasari, Nova. (2019). The Use of Audio Visual Media in Value Clarification Technique to Improvestudent Learning Outcomesin Social Studies. Jurnal Pendidikan. 20 (1). 5368.

Sulfemi, W. B., \& Kamalia, Y. (2020). Jigsaw Cooperative Learning Model Using Audiovisual Media To Improve Learning Outcomes. JPsd (Jurnal Pendidikan Sekolah Dasar). 6 (1), 30-42.

Sulfemi, W. B. (2020). Pengaruh Sarana Prasarana Sekolah Dengan Motivasi Mengajar Guru di SMA Negeri Pamijahan Kabupaten Bogor. Jurnal Ilmiah Edutecno, 22(1), 1-19.

Sulfemi, W. B. (2020). Pengaruh Rasa Percaya Diri dan Gaya Kepemimpinan Kepala Sekolah Terhadap Kinerja Guru. Nidhomul Haq : Jurnal Manajemen

Pendidikan Islam, 5(2), 157-179. https://doi.org/10.31538/ndh.v $5 \mathrm{i} 2.557$

Sulfemi, W. B., \& Yasita, O. (2020). Dukungan Sosial Teman Sebaya Terhadap Perilaku Bullying. Jurnal

Pendidikan, 21(2), 133-147. https://doi.org/10.33830/jp.v21 i2.951.2020

Sutomo, dkk. 2008. Manajemen Sekolah. Semarang : Unnes Press

Tim Penyusun (2006) Program Pengembangan Dosen Non Guru Besar. Universitas Pendidikan Indonesia

Zeithaml. V. Et. Al. (1996). Service Marketig. McGraw-Hill International Edition. 